\title{
MEGESTROL ACETATE: ITS EFFECT ON THE INHIBITION OF OVULATION IN SQUIRREL MONKEYS, SAIMIRI SCIUREUS*
}

\author{
R. M. HARRISON AND W. R. DUKELOW $\dagger$ \\ Endocrine Research Unit, Michigan State University, \\ East Lansing, Michigan 48823, U.S.A.
}

(Received 23rd Fuly 1970, revised 30th November 1970)

Summary. Ovulation induced in squirrel monkeys is completely blocked by daily injections of $500 \mu \mathrm{g}$ of megestrol acetate. Levels of 50 to $250 \mu \mathrm{g}$ either do not inhibit or only partially inhibit ovulation.

The present study on the inhibition of induced ovulation in non-human primates was undertaken as a sequel to earlier work on the induction of ovulation in rhesus (Macaca mulatta) and squirrel (Saimiri sciureus) monkeys. The principal contributors to these earlier investigations were Simpson \& van Wagenen $(1958,1961)$, whose review of the work covering 25 years was published in 1968 (van Wagenen, 1968). Bennett (1967a, b) used PMSG and HCG on squirrel monkeys regardless of the stage of their reproductive cycles. He determined ovulation by laparotomy and reported multiple ovulations and recovered ova.

In 1970, we reported a procedure whereby single and multiple ovulations were repeatedly induced in the squirrel monkey (Dukelow, 1970). This procedure utilized a pretreatment of $5 \mathrm{mg}$ of progesterone in $0.25 \mathrm{ml}$ of corn oil injected 5 times daily i.m., which established the monkeys in a progesteronedominated state. On Days 6 to 9, the monkeys received a subcutaneous injection of $1 \mathrm{mg}$ FSH (P. Armour-Baldwin Laboratories, Omaha, Nebraska) in $0.2 \mathrm{ml}$ of corn oil. Ovulation was induced with 500 i.u. of HGG (Chorionic Gonadotropin, Ayerst Laboratories, New York, N.Y.) i.v. on the evening of Day 9.

The present study used this same technique to determine the effects of low levels of megestrol acetate (17- $\alpha$ acetoxyprogesterone) on ovulation. The megestrol acetate was dissolved in $0.25 \mathrm{ml}$ of corn oil and injected subcutaneously on Days 6 to 10 of the ovulation regimen, i.e. concomitantly with, and 1 day after, the FsH injections. Control animals were subjected to the ovulation induction system and received $0.25 \mathrm{ml}$ of corn oil. The ovaries were examined, either by laparotomy or with a paediatric laparoscope (Semm, 1969), 36 to $40 \mathrm{hr}$ after the injection of HCG. The monkeys were anaesthetized with

* Published with the approval of the Director, Michigan Agricultural Experimental Station.

$\uparrow$ Center for Laboratory Animal Resources (Division of Comparative Medicine, Laboratory of Comparative Reproductive Physiology); and the Departments of Physiology and Animal Husbandry, East Lansing, Michigan. 
$15.5 \mathrm{mg}$ of sodium pentobarbital intraperitoneally. For laparoscopic examination, the abdomen was distended with $5 \% \mathrm{CO}_{2}$ in air and the organs were manipulated with an ancillary probe; this examination required 5.5 to $6 \mathrm{~min}$ per monkey. The sites of ovulation appeared as distinct, raised, reddish areas and were easily discernible.

Forty-four observations were made in monkeys by laparotomy before the establishment of the laparoscopic technique. Some ova were recovered when the oviducts were flushed during the laparotomy. Since the results of forty-six observations made in twenty-four animals using the laparoscopic technique paralleled the direct laparotomy observations, the data from both techniques were combined in Table 1 . A daily dose of $50 \mu \mathrm{g}$ of megestrol acetate did not reduce the rate of induced ovulation when compared to controls subjected to the same ovulation induction scheme. A level of $500 \mu \mathrm{g}$ completely blocked ovulation while levels of 100 and $250 \mu \mathrm{g} /$ day had dose-related, but nonlinear, effects.

TABLE 1

EFFECTS OF MEGESTROL ACETATE ON INDUCED OVULATION IN SQUIRREL MONKEYS

\begin{tabular}{c|c|c|c|c|c}
\hline $\begin{array}{c}\text { Dose of } \\
\text { megestrol acetate* }\end{array}$ & $\begin{array}{c}\text { No. of } \\
\text { observations }\end{array}$ & $\begin{array}{c}\text { No. } \\
\text { ovulating }\end{array}$ & $\begin{array}{c}\% \\
\text { ovulating }\end{array}$ & $\begin{array}{c}\text { Total no. of } \\
\text { ovulation points }\end{array}$ & $\begin{array}{c}\text { Mean no. of } \\
\text { ovulation points/animal }\end{array}$ \\
\hline Control† & 30 & 18 & 60 & 35 & $1 \cdot 9$ \\
$50 \mu \mathrm{g}$ & 10 & 6 & 60 & 8 & $1 \cdot 3$ \\
$100 \mu \mathrm{g}$ & 20 & 7 & 35 & 7 & 1.0 \\
$250 \mu \mathrm{g}$ & 20 & 4 & 20 & 6 & 1.5 \\
$500 \mu \mathrm{g}$ & 10 & 0 & 0 & 0 & 0 \\
\hline
\end{tabular}

* Corn oil or corn oil with megestrol acetate on Days 6 to 10 .

$\dagger$ Control animals induced to ovulate received $0.25 \mathrm{ml}$ corn oil/day subcutaneously.

Megestrol acetate is being studied as a low-dose oral contraceptive in man (Avendano, Tatum, Rudel \& Avendano, 1970). It had previously been demonstrated (Martinez-Manautou, Cortez, Giner, Aznar, Casasola \& Rudel, 1966) that low levels of progestins will prevent pregnancy in man but allow ovulation to occur. Various workers have suggested that the mechanism of this effect is (1) inhibition of normal sperm capacitation, (2) an increased rate of transport of the gametes through the reproductive tract, (3) an increased spermicidal effect within the cervical mucus, or (4) a combination of these mechanisms. Evidence has been presented in different species to substantiate the effectiveness of these mechanisms (Chang, 1967; Martinez-Manautou, Giner-Velasquez \& Rudel, 1967; Dukelow, Willcox \& Abney, 1969). While the contraceptive action of megestrol acetate in squirrel monkeys has not yet been adequately demonstrated, the present work does indicate that a level of 100 to $250 \mu \mathrm{g}$ of megestrol acetate administered daily for 5 days allows ovulation to be induced in these subjects. Its effects on the other reproductive phenomena mentioned above have not been determined.

What the exact mechanism of action of the low dose of megestrol acetate is remains to be investigated. At present, the combined techniques of controlled, induced ovulation and laparoscopic examination establish a reliable test system 
whereby the effects of various antifertility, pharmacological agents can be studied in primates.

We wish to express our appreciation to $\mathrm{Mr} \mathrm{J}$. Evans and Mr G. Caron for assistance with various phases of the project. This project was supported by USPHS Grant No. 5-PO6-FR00366, to the Center for Laboratory Animal Resources, Contract No. 70-2061 from the Center for Population Research, National Institutes of Health, and NIH Research Career Development Award 1-K04-HD35306-01. The megestrol acetate was supplied by Mead Johnson and Company, Evansville, Indiana, through Dr D. G. Gallo.

\section{REFERENCES}

Avendano, S., Tatum, H. J., Rudel, H. W. \& Avendano, O. (1970) A clinical study with continuous low doses of megestrol acetate for fertility control. Am. F. Obstet. Gynec. 106, 122.

BenNETT, J. P. (1967a) The induction of ovulation in the squirrel monkey (Saimiri sciureus) with pregnant mares serum (PMS) and human chorionic gonadotrophin (HCG). J. Reprod. Fert. 13, 357.

Bennett, J. P. (1967b) Artificial insemination of the squirrel monkey. J. Endocr. 37, 473.

Chang, M. C. (1967) Effects of progesterone and related compounds on fertilization, transport and development of rabbit eggs. Endocrinology, 81, 1251.

Dukesow, W. R. (1970) Induction and timing of single and multiple ovulations in the squirrel monkey. F. Reprod. Fert. 22, 303.

Dukzlow, W. R., Wirlcox, J. E. \& Abney, T. O. (1969) Antiestrogenic control of capacitation. Fedn Proc. Fedn Am. Socs exp. Biol. 28, 706.

Martinez-Manautou, J., Cortez, V., Giner, J., Aznar, R., Gasasola, J. \& Rudel, H. W. (1966) Low doses of progestogen as an approach to fertility control. Fert. Steril. 17, 49.

Martinez-Manautou, J., Giner-Velasquez, J. \& Rudel, H. (1967) Continuous progesterone contraception: a dose relationship study with chlormadinone acetate. Fert. Steril. $18,57$.

Semm, K. (1969) Gynaecological pelviscopy and its instrumentarium. Acta europ. Fertil. 1, 81.

Simpson, M. E. \& VAN WAGenen, G. (1958) Experimental induction of ovulation in the Macaque monkey. Fert. Steril. 9, 386.

Simpson, M. E. \& vaN WAGENEN, G. (1961) Induction of ovulation with human urinary gonadotrophins in the monkey. Fert. Steril. 13, 140.

van WaGenen, G. (1968) Induction of ovulation in Macaca mulatta. Fert. Steril. 19, 15. 